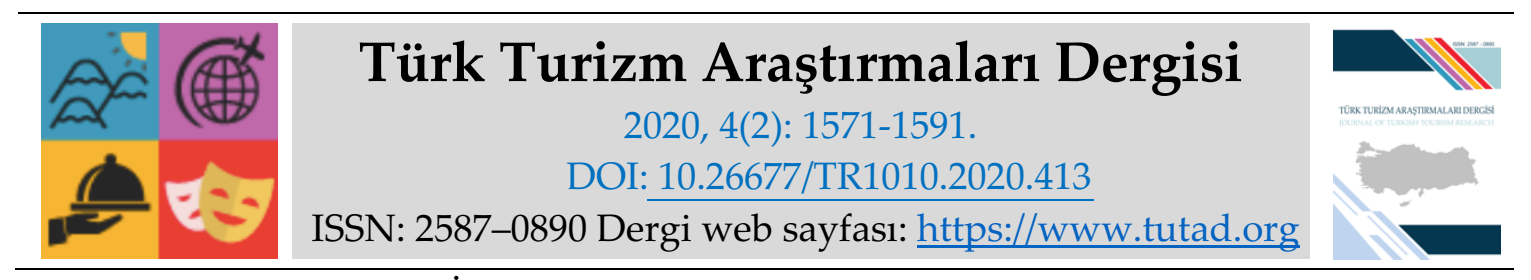

ARASTTIRMA MAKALESI

\title{
Çalışanların Kişilik Özelliklerinin Değişime Açıklığa Etkisi: Eskişehir Restoranları Örneği*
}

Sezer YERSÜREN, Bilim Uzmanı, Anadolu Üniversitesi, Turizm Fakültesi, Eskişehir, e-posta: sezeryersuren@gmail.com

ORCID: https://orcid.org/0000-0001-7511-5345

Dr. Öğr. Üyesi Ebru ZENCİR ÇíFTÇİ Anadolu Üniversitesi, Turizm Fakültesi, Eskişehir, e-posta: ezencir@anadolu.edu.tr

ORCID: https://orcid.org/0000-0001-6668-9961

\section{Öz}

Günümüzde rekabette, bilgi teknolojilerinde, toplumun yaşam biçimlerinde, müşteri beklenti ve ihtiyaçlarında değişimler gerçekleşmektedir. Bu değişimler karşısında ayakta durabilmeleri için, işletmelerin değişime uyum sağlamaları gerekmektedir. İşletmenin değişimi başarıyla gerçekleştirebilmesi için çalışanların değişimi desteklemesi gerekmektedir. Ayrıca, restoran gibi hizmet sektöründe çalışanların kişilik özelliklerinin değişime açık olması, değişimin daha verimli ve etkili olabilmesi açısından önem arz etmektedir. Literatürde değişim ve kişilik özelliklerine ilişkin çalışmalar bulunmakla birlikte, bunları restoran çalışanlarının kişilik özelliklerinin değişime açıklığıyla ilişkilendiren bir çalışmaya rastlanılmamıştır. Bu sebeple, çalışmanın amacı restoran çalışanlarının kişilik özelliklerinin değişime açıklı̆ a olan etkisini incelemektir. Veriler Eskişehir ilinde bulunan 450 restoran çalışanına uygulanmış ve geçerliliği kabul edilen 397 anket analiz edilmiştir. Elde edilen verilerin analizinde nicel araştırma yöntemlerinden yararlanılmıştır. Araştırma verilerinin toplanmasında, geçerliliği ve güvenilirliği kontrol edilen "Değişime Açıklık Ölçeği" ve "Büyük Beşli Kişilik Envanteri" kullanılmıştır. Verilerin analizinde korelasyon analizi, basit doğrusal regresyon analizi, t-testi ve tek yönlü varyans analizi uygulanmıştır. Araştırmanın sonucunda katılımcıların demografik özellikleriyle değişime açıklık arasında anlamlı bir ilişki tespit edilmemiştir. Basit doğrusal regresyon analizi sonucunda kişilik envanterinin geneli itibariyle değişime açıklığa pozitif yönlü etkisinin olduğu sonucuna ulaşılmıştır. Değişime açıklığın, kişilik envanterinin deneyime açıklık, sorumluluk, dışadönüklük ve uyumluluk boyutları ile arasında pozitif yönlü ilişkiler saptanırken duygusal dengesizlik boyutu ile arasında negatif yönlü ilişki tespit edilmiştir.

*Bu makale Sezer YERSÜREN'in yüksek lisans tezinden derlenmiştir.

Anahtar Kelimeler: Kişilik, Kişilik Özellikleri, Değişime Açıklık, Restoran Çalışanları, Eskişehir.

Makale Gönderme Tarihi: 30.12.2019

Makale Kabul Tarihi: 02.04.2020

\section{Önerilen Atıf:}

Yersüren, S. ve Zencir Çiftçi, E. (2020). Çalışanların Kişilik Özelliklerinin Değişime Açıklı̆̆a Etkisi: Eskişehir Restoranları Örneği, Türk Turizm Araştırmaları Dergisi, 4(2): 1571-1591.

(C) 2020 Türk Turizm Araştırmaları Dergisi. 


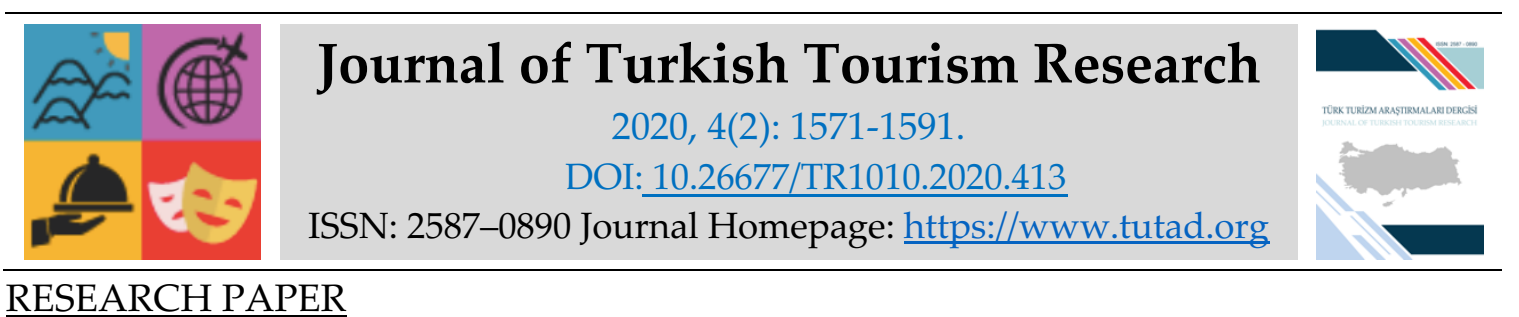

RESEARCH PAPER

\title{
Impact of Employees' Personality Traits on Openness to Change: The Case of Eskişehir Restaurants
}

\author{
Sezer YERSÜREN, MSc., Anadolu University, Faculty of Tourism, Eskişehir, e-mail: \\ sezeryersuren@gmail.com \\ ORCID: https://orcid.org/0000-0001-7511-5345
}

Assistant Prof. Ebru ZENCİR ÇİFTÇİ, Anadolu University, Faculty of Tourism, Eskişehir, e-mail: ezencir@anadolu.edu.tr

ORCID: https://orcid.org/0000-0001-6668-9961

\begin{abstract}
Today, there are changes in competition, information technologies, society's lifestyles, customer expectations and needs. If any firm wants to stay strong in this changing world, it needs to be able to adapt to change. In order for the firm to be through with the change successfully, employees need to support the change. Also, in the service industry such as restaurants, it is crucial that personality traits of employees are open to change to change, for the change to be more efficient and effective. Although there are studies on change and personality traits in literature, there seems to be none correlating these with the openness to change of restaurant employees' personality traits. For this reason, the aim of this study is to examine the impact of restaurant employees' personality traits on openness to change through those located in Eskişehir city. The data were applied to 450 employees in Eskişehir restaurants using the questionnaire technique and 397 questionnaires which are accepted to be applicable were analyzed. Quantitative research methods were used in the analysis of the obtained data. "Openness to Change Scale" and "Big Five Personality Inventory" which were tested for reliability and validity, were used to collect the research data. In the analysis of the data, t-test, correlation analysis, one-way analysis of variance and simple linear regression analysis were applied. As a result of the study, no significant relationship was found between the demographic characteristics of the participants and openness to change. The simple linear regression analysis resulted that, in general, there exists a positive effect of the personality inventory on the change in openness. It is determined that openness to change is negatively correlated with the neuroticism dimension of the personality inventory, whereas it is positively correlated with openness to experience, conscientiousness, extraversion, and agreeableness dimensions.
\end{abstract}

Keywords: Personality, Personality Traits, Openness to Change, Restaurant Employees, Eskişehir. Received: 30.12 .2019

Accepted: 02.04 .2020

Suggested Citation:

Yersüren, S. and Zencir Çiftçi, E. (2020). Impact of Employees' Personality Traits on Openness to Change: The Case of Eskişehir Restaurants, Journal of Turkish Tourism Research, 4(2): 1571-1591.

(C) 2020 Türk Turizm Araştırmaları Dergisi. 


\section{Gíriş}

İlk insanın doğanın sahip olduğu güçlere, vahşi hayvanlara ve zorbalara karşı koymak amacıyla kader ve güç birliği yapmak üzere bir araya gelmesi, yönetimin insanlık tarihi kadar eskilere dayandığının bir göstergesi olarak nitelendirilebilir (Şimşek, 2002). İkinci Dünya Savaşı'ndan sonra yönetim bilimi alanında eskiye oranla yepyeni düşünceler gündeme gelmeye başlamış (Şahin, 2008), klasik yönetim ve örgüt teorisinde evrim niteliğinde değişme ve gelişmeler yer almıştır (Baransel, 1993: 12). 20. yüzyılın son çeyreğine gelindiğinde dünyada başta ekonomik, sosyal, siyasal ve kültürel alanlar olmak üzere hemen hemen her alanda çok hızlı ve köklü gelişmeler ve değişmeler yaşanmaya başlamıştır. Temelde bilim ve teknolojideki ilerlemelere bağlı olarak ortaya çıkan bu gelişme ve değişmeler bireysel ve toplumsal yaşamı olduğu kadar, örgütleri de derinden etkilemiştir (Çavuş, 2008: 20-21). Günümüzde değişim ve değişimin yönetilmesi, işletmelerin hayatta kalmak ve ötesinde güçlü olmak için başarı ile aşmaları gereken engelden çok, sürekli takip etmeleri ve bir örgütsel politika haline getirmeleri gereken bir süreç haline gelmiştir.

Değişimin gerçekleştirilmesinde insanın payı büyüktür. İnsanın olduğu yerde bireyin sahip olduğu kişiliğin etkisinin de olduğu aşikardır ve karakteristik özelliklerinin de rolü büyüktür. Değişim sürecinin başarılı sonuçlar vermesi için çalışanların değişime açık olması ve değişimi desteklemeleri gerekmektedir. Dolayısıyla değişim içerisinde yer alan çalışanların kişilik özelliklerinin değişime açık olması sürecin verimliliği ve etkinliği açısından önem arz etmektedir. Çünkü değişime gösterilen direnç, süreci olduğu kadar işletmeyi de olumsuz etkileyecektir. Özellikle restoran gibi hizmet yoğun işletmelerde çalışanların değişime karşı gösterdikleri tepki, işletmenin devamlılı̆̆ üzerinde önemli etkiye sahiptir. Dolayısıyla değişimi düşünen işletmelerin, çalışanların kişiliklerini de göz ardı etmemeleri gerekmektedir. Literatürde kişilik özellikleri ve değişimin birlikte incelendiği bir çalışmaya rastlanılmamış olması bu çalışmanın gerçekleştirilmesinin ana sebebidir. Çalışmanın konuya ilişkin alanyazına katkı sunacak olması, işletmelerin değişim öncesi ve sürecinde çalışanlarının kişilik özelliklerinin dikkate alınması gerekliliğini vurgulaması çalışmanın önemi olarak gösterilmektedir. Bu bağlamlar doğrultusunda çalışmanın amacı; restoran çalışanlarının kişilik özelliklerinin değişime açıklığa olan etkisinin incelenmesidir. Çalışma sonucunda kişiliğin değişime açılığı etkilediği görülmüştür. Dolayısıyla değişimi düşünen işletmelerin, çalışanların kişilik özelliklerini dikkate almalarının önem arz ettiği söylenebilir. Ayrıca işletmelerin değişim sonrasında başarılı sonuçlar elde edebilmesi noktasında değişime açık kişilik yapısındaki kşilerin etken bir rol üstlendiğini söylemek mümkündür.

\section{DEĞİŞIM VE DEĞİŞİME AÇIKLIK}

Değişim, doğanın işleyişinden insan unsuruna, örgütsel yapılardan işletme yönetimlerine, tarihsel dönemlerden yönetim yaklaşımlarına kadar birçok alanda etkisini hissettirmektedir. Değişim gerçekliğinin temelinde değişmeyen tek şeyin değişimin kendisi ve sürekli olduğudur. Değişim; "Mevcut olan durumun, iletişim ve irtibat halinde olunan çevre koşullarının ihtiyaçları karşısında, artık çaresiz ve kayıtsız kalması durumunda, örgütü yeniden yapılandıracak ve ihtiyaçları giderebilecek düzeyde yeni fikirler üretebilme ve bunu uygulama süreci" olarak nitelendirilebilmektedir (Kozak ve Güçlü, 2003: 1).

Değişim, tüm sosyal sistemlerin kültürlerini ve yönetim biçimlerini bilgi artışı, hızlı gelişmeler ve iletişimdeki ilerlemelerle derinden etkilemektedir. Her alanda yükselen yeni değerler, toplumları ve işletmeleri geleneksel değerlerden vazgeçmeye itmektedir (Örs ve Tetik, 2010: 443). Hiçbir şey günümüzde durağan ve basit değildir. Değişimin sürekli olduğu bu gerçeklikte işletmelerin çevresi de duruma kayıtsız kalmayarak hızlı, radikal ve şaşırtıcı bir şekilde değişmektedir (Champy, 1995: 9 ve Hammer ve Champy, 1994). İşletmeler de ayakta kalabilmek için değişime ayak uydurmak zorunda kalmışlardır (Gök, 2016: 31). Değişimin sistematik bir çerçevesi olsa da insan unsuru tarafından gerçekleştirildiği yadsınamaz. Dolayısıyla değişimin başarısında çalışanın değişimi desteklemesi ve değişime katkı sağlaması önemlilik arz etmektedir. İşletmenin değişime açık olmasının yanında çalışanların da değişime açık olmaları gerekmektedir (Manganelli ve Klein, 1994 ve Simon, 1994: 33). 
Burada önemli olan çalışanların değişime psikolojik ve davranışsal olarak hazır olmalarıdır (Weiner, vd., 2008). Çünkü değişim sonucunda beklenen hedeflere ulaşılması açısından çalışanların değişim yanlısı olması önem teşkil etmektedir. Ayrıca değişim karşıtı tepkiler değişimin uygulanmasını zorlaştırabilmektedir (Andrews ve Stalick, 1994: 27-28). Andrews ve Stalick (1994), Kozak (2004), Devos, vd., (2007) ve Koçel (2015) değişimin tüm organizasyonun desteğiyle gerçekleşebileceğini vurgulamaktadır.

Değişimin başarılı sonuçlar verebilmesi için çalışanların değişime açı olması gerekmektedir. Bunun için bireylerin bilişsel ve duygusal olarak değişimi benimsemeleri ve değişimin hedefleri doğrultusunda çalışanların hareket etmeleri gerekmektedir (Holt vd., 2007: 235). Ayrıca çalışanların değişim için hazır olması ve değişimi desteklemesinin işletmenin değişim sonrası hedeflerine ulaşmasında etken rol üstlenebileceği söylenebilir (Armenakis ve Harris, 2002). Cochran, Bromley ve Swanda (2002) güvenlik alanında yaptıkları çalışmada; değişime açıklığı, değişime karşı pozitif tutum ve pozitif duygulara sahip olmak şeklinde ifade etmektedir. Değişimi gerçekleştirmek için çalışanın gerekli beceriye sahip olması ve değişimin içerisinde destekler nitelikte yer alması değişime açılığın gelişmesine katkı sağlar (Cunningham vd., 2002: 377). Ayrıca değişime açıklığı oluşturmak için birçok çalışanın bireysel algıları değiştirilmelidir. Farklı bilişsel düzeylere sahip çalışanların algı düzeyleri de farklı olacaktır. Dolayısıyla bu kişilerin değişime hazır olmasının sağlanması gerekmektedir (Armenakis, vd., 1993). Ayrıca değişime açıklık konusunda kültürel etkilerin olduğu ve göz ardı edilmemesi gerektiği de belirtilmektedir (Morris vd., 1998).

Dünyada değişimin sistematik uygulaması konusunda çalışmalar yürüten birçok işletme yer almaktadır (Hammer ve Santon, 1995). Bu işletmeler içinde Ritz Carlton, ITT Sheraton, Radisson, Hilton (Aksu, 1999: 153) gibi zincir otel işletmelerinin ve Taco Bell (yiyeceklerin hazırlanma sürecinde kullanılmıştır) gibi yiyecek içecek işletmelerinin de yer aldığı görülmektedir. Cox vd., (2011) yaptıkları çalışmada restoran işletmelerinin değişime ayak uydurması gerektiğini belirtmektedirler. Ayrıca Sidney'de bulunan bir restoran değişime giderek "Yaratıcılık" departmanı oluşturmuştur ve TripAdvisor'da birinci sırada tercih edilen işletme olarak yer almıştır (Albayrak, 2017). Bu durum değişimin hizmet yoğun işletmelerde de uygulanabileceğinin bir kanıtı olarak belirtilebilmektedir. Burada önemli olan değişimi gerçekten anlamak ve gerçekçi hedef ve vizyon doğrultusunda değişimi topyekün destekleyerek uygulayabilmek olduğu söylenebilir. Değişimin başarısı için çalışanların değişime açık olması ve değişimi desteklemeleri kilit rol üstlenmektedir. Çalışanların değişim yanlısı davranışlarda bulunarak değişime katkı sunması önemlidir. Değişim içerisinde çalışanların davranışlarını belirleyen etkenlerden biri de sahip oldukları kişilik özellikleridir. Kişilik özellikleri çalışanın iş çevresine uyumunu, performansını, tutumlarını ve davranışlarını belirleyen önemli bir unsurdur. Dolayısıyla çalışanların kişilik özelliklerinin değişime açık olması değişimin başarılı şekilde gerçekleştirilmesi açısından dikkate alınması gereken bir konudur.

\section{Kişilik ve Kişilik Özellikleri}

Kişilik kavramı, 1930'lu yıllarda, kişilik psikolojisinin ayrı bir bilimsel disiplin olarak ortaya çıkmasıyla başlamaktadır (Mc Adams, 1997). Geçmişten günümüze kadar kişilik farklı açılardan incelenmiş ancak araştırmacılar ortak bir kişilik tanımlamasında bulunamamıştır (Şimşek, 2006: 18 ve Baymur, 1996: 251). Ortak bir paydada buluşulamamasının, kişiliğin karmaşık ve çok yönlü bir yapıda olması ve araştırmacıların kişilik kavramını kendi alanlarına göre yorumlaması, bir neden olarak söylenebilir.

Kişilik, yaşamı sürdürmenin temeli şeklinde yorumlanabilir. Tutumlar, beceriler, hoşlanılan ve hoşlanılmayan şeyler, bireyin kendini nasıl gördüğü, bir bireyin yaşamı boyunca tekrarladığı, belirgin bir biçimde tek bir kişiye ait olan davranışın kökleri olarak nitelendirilmektedir (Drake ve Smith, 1978: 59). Bazı araştırmacılar ise kişiliği, fiziksel, zihinsel ve tinsel özelliklerin bir karışımı olarak; görünüş, düşünce, davranış ve duyguların kişiliğe yansıması şeklinde ifade etmektedirler (Schermerhorn vd., 2000: 64-65; George ve Jones, 1996: 34-35; Hellriegel ve Slocum, 2004: 38; Usal ve Aslan, 1995: 72; Ertürk, 2010: 57; Şimşek, vd., 2003: 73; Usal ve Kuşluvan, 1998 ve Yelboğa, 2006: 198). Allport ise 50'ye yakın 
kişilik tanımını inceleyerek bu tanımların kişiliğin davranışsal, sosyal uyarıcı ve derinlik psikolojisi kapsamında yapılan tanımlar olmak üzere üç kategori altında toplamaktadır. Bu incelemeler doğrultusunda Allport (1937) kişiliği, "bireyin çevresine özgün ve farklı bir biçimde uyumunu belirleyen psikofiziksel sistemlerin dinamik bir bütünleşmesi olarak" tanımlamaktadır (Tolan vd., 1991: 120). İlerleyen yıllarda ise kişilik özellikleri kuramsal olarak ele alınmaktadır.

Kişilik özellikleri kuramı, bir insanın belirli bir kişilik özelliğini ne seviyede gösterdiğine göre bireyi kategorize eden bir kişilik boyutudur. Bu kuramın temelinde kişilik özelliklerinin kararlılık gösterdiği ve değişmez olduğu yer almaktadır. Bireyin davranışının nedeniyle değil, kişiliği betimlemek ve davranışı kestirebilmekle ilgilenmektedir (Burger, 2006: 236-237). Kişilik özelliklerini, kullanıma uygun hale getirebilmek için dildeki sıfatların kullanımına başvurulmaktadır. Klages (1926), Baumgarten (1933) ve Allport ve Odbert (1936) insanların doğal dilini bireylerin kişiliğinin anlaşılmasına dair bir kaynak olarak belirtmektedirler (John vd., 1988: 175-176). Kişilik tanımlama terimlerinin incelenmesi ile özellikle de sıfatların temsili bir örneklemesinin, kişilik özelliklerinin temsili bir örneğini verebilir olması, dil ve kelimeler ile olan bir bakış açısının geliştirilmesine olanak tanımaktadır (Saucier ve Goldberg, 1996: 62-63).

Allport ve Odbert ile başlayan Catell ve Eysenck ile süregelen kişiliğin özellikler çalışmaları McCrae ve Costa ile gelişimini tamamlamaktadır. Araştırmalar sonucunda beş faktörün üzerinde durulmaktadır. Birbirinden farklı faktörler içeren ve pek çok değişik yöntemlerle yapılan çalışmalar sonucunda sadece beşli faktörün süreklilik ve tutarlılık gösterdiği görülmektedir. Catell ve Costa ve McCrae'nin geliştirdikleri modeller işletmelerde yapılan araştırmalarda sorunlarla karşılaşılması nedeni olarak bu modellerin klinik ya da iş haricindeki kişilik değerlendirmeleri çerçevesinde oluşturulması gösterilmektedir (Aydoğmuş, 2011: 21-23). Goldberg (1992)'in geliştirdiği modelde yer alan sıfatlar tek başına değerlendirildiğinde açık bir şekilde anlaşılamadığından karmaşaya yol açtı̆̆ belirtilebilmektedir (McCrae ve Costa, 1985, 1987, 2003). Beş Faktör Modelinin faktörleri üzerinden giderek John, Donahue ve Kentle (1991) tarafından oluşturulan 5 boyut 44 maddeden oluşan ölçeğin daha kısa, anlaşılır ve kullanımının etkili olduğu söylenebilmektedir. Ölçeğin kısa olması hem zamanın etkin kullanılmasını hem de yanıtlayıcıların daha istekli ve rahat olmalarını sağlayabilmektedir (Burisch, 1984: 218-219). Zamanla Beş Faktör Modeli'ndeki özellikler evrensel olarak kabul görmüştür. Yaygın bir kullanımı olmasının yanında temel kişilik özelliklerinin boyutları açısından en etkili model olarak görülmektedir (Burger, 2006; Schmitt vd., 2007; Feist ve Feist, 2008; Heine ve Buchtel, 2009 ve Myers ve Dewall, 2017: 590). Özellikle kişilik özelliklerinin ve büyük beşli kişilik envanterinin son yıllarda işçi alımlarında, iş performansı ve değerlendirmesinde ve bireyin iş çevresine uyumunun tahmin edilmesi açısından önemli ve kullanılabilir olduğu görülmektedir (Salgado, vd., 2001; Matthews, 1997; Hough, 1992 ve Burger, 2006). Yukarıda bahsedilen Beş Faktör Modeli; “dışadönüklük, uyumluluk, sorumluluk, duygusal dengesizlik ve deneyime açılık" boyutlarından oluşmaktadır.

Boyutlar ayrı ayrı incelendiğinde, kişilik özelliklerinin birbirine zıt iki kutuptan meydana geldiği görülmektedir. Dışadönük insanların değişime daha açık olduğu ve bu kişilik profilindeki kişilerin işletmelerin değişim düşüncelerine pozitif etkileyeceği tahmin edilmektedir. Moberg (2001: 50) yaptığ1 çalışmada uyumluluk ile uzlaşma arasında olumlu bir ilişki olduğu sonucuna ulaştığı görülmektedir. Uyumlu kişiler sahip oldukları ilişkileri kaybetmemek için iş birliğine yakındır. Geleneksel yöntemlerle işlerini yapmaktadır (Sun ve Jin, 2009). Barrick vd., (2002) uyumlu kişilerin takım çalışmalarında etkili olduğu ve iş yaşantısında karşılıklı etkileşim sağlayan işlerin daha uygun olduğunu belirtmektedir. Uyumlu kişilerin yaratıcı özelliklerinin fazla olmamasına karşın değişimi düşünen işletmelerde oluşturulan değişim mühendisliği ekibinin uyumluluk özelliği yüksek olan kişilerce oluşturulması, sürecin daha verimli sürdürülmesi açısından etkili olabileceği varsayılabilir. Sorumluluk duygusu fazla olan bireylerin üstlendiği işleri ve görevleri etkili bir şekilde tamamlamak için gereken çabayı gösterir ve sonuçlarına katlanır (Özen, 2011: 82). Sorumluluk duygusu yüksek olan kişiler ihtiyatlı davranırlar. Riskin getirdiği belirsizlikten dolayı risk almayı sevmezler (Raja, vd., 2004: 352). Duygusal dengesizliğe sahip bireylerin iş doyumu ve tatmini oldukça düşük olmasına rağmen kendilerine olan güvensizlikleri nedeniyle işten çıkma eğilimi göstermezler. Bu tarz kişiler sosyal ilişkilerde oldukça zayıftır ve kontrol 
altına geçmek istemezler (Raja, vd., 2004 ve Somer, vd., 2002). Değişim oldukça riskli ve zor bir süreçtir. Böylesi hayati bir aşamada işletmenin duygusal açıdan dengesiz kişilerle birlikte çalışması değişimin başarısının negatif yönlü seyir izlemesine neden olabilir. Deneyimlere açık olan kişiler yeniliğe ve değişime karşı açık olan ve destekleyen kişiler olarak görülmektedir (Judge ve Bono, 2000: 753). Deneyime açık olmayan bireyler otoriteye itaat eden, gelenekselci ve ilgi alanları dar olan bireyler olduklarından alışıldığın dışına çıkmayan görevleri gerçekleştirmek isterler (Feist ve Feist, 2008: 423). Değişimi gerçekleştirmek isteyen işletmelerin direncin en az olduğu deneyime açıklık özelliği gösteren kişilerle çalı̧̧ması istenen hedeflerin gerçekleştirilmesi açısından işletmeye katkı sağlayacağ düşünülebilmektedir. Ayrıca dışadönüklük, uyumluluk ve sorumluluk özelliği taşıyan çalışanların eğitim, ödüllendirme ve iyi bir yönetimle değişime katkı sunabileceği söylenebilir. Kişilik, yukarıda bahsedildiği üzere birçok alanda kullanıldığı gibi hizmet sektöründe de kullanımı söz konusudur. Otel çalışanlarının kişilik özellikleri üzerine Akgündüz ve Akdağ (2014), Develioğlu ve Tekin (2013), Tan (2017) ve Yıldırım (2014) çalışmalar gerçekleştirmiştir. Ayrıca Arslan (2017), Özkan (2017) ve Serçeoğlu (2013) otel çalışanları üzerine yaptıkları çalışmalarda duygusal dengesizlik özelliğinin araştırmaları üzerinde negatif etkisi olduğu diğer kişilik boyutlarının ise pozitif etkisinin olduğu sonucuna ulaştıkları görülmektedir. Şimşek ve Çetinkaya (2017) ise yiyecek ve içecek işletmeleri çalışanlarının kişilik özelliklerine ilişkin çalışma gerçekleştirmiştir. Yukarıda belirtilen çalışmalar kişiliği beş boyut altında incelemektedir. Ancak yararlanılan ölçekler farklı araştırmacıların geliştirmiş olduğu ölçeklerdir. Bu bilgiler kapsamında, kişilik kavramının hizmet sektöründe de önemli yer tuttuğu ve işletmelerce dikkate alınması gereken etkenlerden biri olduğu ifade edilebilir.

Alanyazında yer verilen bütün bu açıklamalar dikkate alındığında çalışanların kişilik özelliklerinin değişime açıklı̆ga etki edeceği varsayılabilir. Bu noktadan hareketle çalışmanın araştırma sorusu; çalışanların kişilik özellikleri değişime açıklığı etkilemekte midir? şeklinde oluşturulmuştur. Çalışmanın amacı doğrultusunda oluşturulan temel hipotezin yanı sıra değişim ve kişilik değişkenlerini daha detaylı incelemek için değişkenlerin alt boyutları da esas alınmış ve aşağıdaki şekilde hipotezler geliştirilmiştir:

H1: Çalışanların kişilik özellikleri değişime açıklığı etkiler.

H1a: Çalışanların deneyime açıklık özelliği değişime açıklığı etkiler.

H1b: Çalışanların sorumluluk bilinci değişime açıklığı etkiler.

H1c: Çalışanların dışadönüklüğü değişime açıklığı etkiler.

H1d: Çalışanların duygusal dengeleri değişime açıklığı etkiler.

H1e: Çalışanların uyumluluğu değişime açıklığı etkiler.

H1f: Çalışanların kişilik özellikleri değişimin davranışsal boyutunu etkiler.

H1g: Çalışanların kişilik özellikleri değişimin bilişsel boyutunu etkiler.

H1h: Çalışanların kişilik özellikleri değişimin duygusal boyutunu etkiler.

\section{YÖNTEM}

Araştırmada restoran çalışanlarının kişilik özelliklerinin değişime açıklığa etkisini incelemek için nicel yöntemlerden yararlanılmıştır. Veri toplama aracı olarak ise anket tekniği kullanılmıştır. Alanyazın incelemesi sonucu oluşturulan anket formu üç bölümden oluşmaktadır. Birinci bölümde çalışanların demografik özelliklerinin belirlenmesi amaciyla dokuz soru sorulmuştur. İkinci bölümde Dunham vd., (1989) tarafından oluşturulan Klecker ve Loadman (1999) tarafından geliştirilen Bingül (2006) tarafından Türkçeye çevrilip uygulanmış olan davranışsal, duygusal ve bilişsel boyutlardan oluşan değişime açıklık (Opennes to Change) ölçeğinden yararlanılmıştır. Anketin üçüncü bölümünde çalışanların kişilik özelliklerini ölçmek için John, Donahue ve Kentle (1991) tarafından geliştirilmiş olan Büyük Beşli Kişilik Envanteri- BBKE (Big Five Inventory- BFI) kullanılmıştır. Bu ölçeğin evrensel olarak kabul görmüş olması, 56 farklı ülke ve kültürde uygulanmış olması, yaygın kullanımı ve diğer kişilik ölçeklerine göre daha az ifade bulundurmasının kullanımını kolaylaştırması sebebiyle tercih edilmektedir (Feist ve Feist, 2008; Heine ve Buchtel, 2009; Myers ve Dewall, 2017: 590; Burger, 2006 ve 
Schmitt vd., 2007). Büyük Beşli Kişilik Envanteri; “dışadönüklük, uyumluluk, sorumluluk, duygusal dengesizlik ve deneyime açıklık" olmak üzere 5 boyut ve 44 maddeden oluşmaktadır. Ölçeklerin farklı kültürlerde ve farklı alanlarda (sektör) uygulanması halinde öncelikle soru formlarının en az 5 uzman tarafından incelenmesi gerektiği ifade edilir (Lester vd., 2014). Bu çalışmada ölçeklerin kapsam ve geçerliliğini tespit etmek için alanında uzman 9 akademisyen ile görüşülmüştür. Uzman görüşleri doğrultusunda yer alan kişilik ölçeğinde bazı ifadelerin birden fazla anlam taşıdığı belirtilmiş ve uzman görüşleri dikkate alınarak düzenlenen form 49 ifade olarak kullanılmıştır.

Anket formunda uzman görüşüyle değişiklikler yapıldığı için 17.12.2017- 01.01.2018 tarihleri arasında Eskişehir ilinde masa hizmeti ve alakart hizmeti veren restoranlarda çalışan 69 katılımcıya pilot anket uygulanmıştır. Eksik doldurulan anketler çıkartılarak geriye kalan 60 anket analize tabi tutulmuştur. Pilot çalışmada belirli istatistiki analizlerin yapılabilmesi için en az 30 katılımcının olması gerektiği kabul edilebilmektedir (Altunışık, vd., 2001). Pilot çalışmada değişime açılık ölçeğinin Cronbach alpha katsayısı 0.810 iken kişilik ölçeğinin Cronbach alpha katsayısı ise 0.793 olarak saptanmıştır. Cronbach alpha güvenilirlik katsayısının 0.70 veya daha yüksek olması durumunda ölçeğin güvenilir ve yeterli olduğu kabul edilmektedir (Nunnally, 1978). Pilot çalışmada ölçeklerin kabul edilebilir bir değere sahip olması doğrultusunda temel çalışmaya geçilmiştir.

\section{Araştırmanın Evreni ve Örneklemi}

Araştırmanın evrenini Eskişehir ilinde bulunan alakart ve masa hizmeti veren restoran çalışanları oluşturmaktadır. Araştırmada örneklemin belirlenebilmesi için öncelikle İl Kültür ve Turizm Müdürlügü ve belediye kayıtları araştırılmıştır. Ancak gerek İl Kültür ve Turizm Müdürlüğü gerekse belediye kayıtlarında işletmelerin çalışan kayıtlarına ulaşılamamıştır. Bu nedenle olasılığa dayalı olmayan örnekleme türlerinden kolayda örneklem kullanılmıştır. Kolayda örnekleme belirli bir mekandaki herkese belirli bir zamanda ulaşılması şeklinde belirtilir ve yaygın olarak kullanılan bir yöntemdir (Kozak, 2015: 118; Yazıcıŏ̆lu ve Erdoğan, 2014: 83). Eskişehir'deki restoran işletmelerinin sayısının belirsiz olması ve bu işletmelerin içinde alakart ve masa hizmeti vermeyen (dönerci, kokoreççi gibi) işletmelerin de varlığının söz konusu olması araştırma evrenin belirsizliğini göstermektedir. Araştırma evreninin belirsiz olduğu durumlarda, örneklem büyüklügünün \%95 güvenilirlik düzeyi heterojen varsayımının 384 olduğu belirtilmektedir (Kozak, 2015: 113). Bu araştırmada elde edilen veriler Eskişehir'de yer alan alakart ve masa hizmeti veren restoranlarda çalışanlar ile sınırlıdır. Bu sebepten ötürü sonuçların tüm restoranlar için genellenmesi mümkün değildir.

\section{Verilerin Toplanması ve Analizi}

Araştırmada veriler Eskişehir ilindeki restoran çalışanlarından anket yoluyla 10.01.2018 - 07.03.2018 tarihleri arasında toplanmıştır. Anketlerin bazıları araştırmacı tarafından yapılabileceği gibi bırak-al şeklinde de yapılabilmektedir (Coşkun, 2015: 82-83). Hizmet sektöründe yer alan restoranların işleyişinin hızlı ve yoğun olması ve işletme sahiplerinin işleyişin aksaması açısından taşıdıkları kaygılar sebebiyle çalışanların ancak molalarında ya da boş vakitlerinde doldurmalarına izin vermesi nedeniyle her iki teknik de kullanılmıştır. Eskişehir de bulunan alakart ve masa hizmeti veren restoran çalışanları üzerine yapılan çalışmada 450 kişiye anket uygulanmış ve geçersiz anketler çıkartılarak 397 anket geçerli sayılmıştır (geçerli anket oranı \%88,2). Araştırmada elde edilen veriler, istatistik paket programı (SPSS 24) kullanılarak analiz edilmiştir. Öncelikle elde edilen verilerin parametrik veya parametrik olmayan analiz yöntemlerinden hangileri ile analiz edileceğinin tespiti için verilerin normal dağılıp dağılmadığına bakılmıştır. Yapılan inceleme sonucunda basıklık ve çarpıklık değerlerinin normal dağılım olarak kabul edilebilecek $-1,5$ ile $+1,5$ aralığında olduğu tespit edilmiştir (Tabachnick ve Fidell, 2007). Çalışanların kişilik özelliklerinin değişime açılığa ilişkin tutumlarının demografik özelliklerine göre değişkenlik gösterip göstermediğine ilişkin incelenmesi açısından bağımsız örneklem t-testi ve One-way Anova uygulanmıştır. Sonrasında verilere açıklayıcı faktör analizi uygulanmıştır. Ayrıca 
değişkenlerin birbiriyle olan ilişkilerin incelenmesi kapsamında korelasyon analizi ve kişilik özelliklerinin değişime olan etkisini ölçmek adına regresyon analizi yapılmıştır.

\section{BULGULAR VE YORUM}

Araştırmada ilk olarak anketin birinci bölümünde yer alan demografik veriler analiz edilmiştir. Analiz sonuçları Tablo 1'de verilmiştir.

Tablo 1. Katılımcıların demografik özellikleri

\begin{tabular}{|c|c|c|c|c|c|}
\hline \multicolumn{6}{|c|}{ Demografik Özellikler } \\
\hline Cinsiyet & (f) & $(\%)$ & Çalışma Durumu & (f) & $(\%)$ \\
\hline Erkek & 225 & 56,7 & Sürekli & 297 & 74,8 \\
\hline Kadın & 172 & 43,3 & Part-time & 90 & 22,7 \\
\hline Toplam & 397 & 100,0 & Diğer & 10 & 2,5 \\
\hline Yaş Grupları & (f) & $(\%)$ & Toplam & 397 & 100,0 \\
\hline $18-25$ & 216 & 54,4 & Meslek Grupları & (f) & $(\%)$ \\
\hline $26-33$ & 119 & 30,0 & Temizlik görevlisi & 21 & 5,3 \\
\hline $34-41$ & 32 & 8,1 & Servis görevlisi & 197 & 49,6 \\
\hline $42-49$ & 19 & 4,8 & İşletme yöneticisi & 41 & 10,3 \\
\hline 50 ve üzeri & 11 & 2,8 & Bar personeli & 32 & 8,1 \\
\hline Toplam & 397 & 100,0 & Mutfak personeli & 44 & 11,1 \\
\hline Gelir Durumu & (f) & $(\%)$ & Mutfak şefi & 31 & 7,8 \\
\hline 1500 ve altı & 123 & 31,0 & Kasiyer & 19 & 4,8 \\
\hline $1501-2500$ & 249 & 62,7 & Karşılama görevlisi & 6 & 1,5 \\
\hline $2501-3500$ & 17 & 4,3 & Stok görevlisi & 6 & 1,5 \\
\hline 3501 ve üzeri & 8 & 2,0 & Toplam & 397 & 100,0 \\
\hline Toplam & 397 & 100,0 & Toplam İş Tecrübesi & (f) & $(\%)$ \\
\hline Eğitim Durumu & (f) & $(\%)$ & 1 yıldan az & 24 & 6,0 \\
\hline İlköğretim & 51 & 12,8 & $1-5$ & 206 & 51,9 \\
\hline Lise & 91 & 22,9 & $6-10$ & 115 & 29,0 \\
\hline Ön lisans & 65 & 16,4 & $11-15$ & 25 & 6,3 \\
\hline Lisans & 169 & 42,6 & 16 yıl ve üzeri & 27 & 6,8 \\
\hline Lisansüstü & 21 & 5,3 & Toplam & 397 & 100,0 \\
\hline Toplam & 397 & 100,0 & Kurumdaki Çalışma Süresi & (f) & $(\%)$ \\
\hline Medeni Durum & (f) & $(\%)$ & 1 yıldan az & 163 & 41,1 \\
\hline Evli & 79 & 19,9 & $1-5$ & 211 & 53,1 \\
\hline Bekâr & 318 & 80,1 & $6-10$ & 19 & 4,8 \\
\hline Toplam & 397 & 100,0 & 16 yıl ve üzeri & 4 & 1,0 \\
\hline & & & Toplam & 397 & 100,0 \\
\hline
\end{tabular}

Ankete katılan katılımcıların cinsiyet dağılımının birbirine yakın olduğu anlaşılmıştır. Bilindiği gibi yiyecek-içecek işletmeleri emek yoğun bir sektördür ve çalışanların dinamik ve yoğun iş temposuna (Tuncer ve Yeşiltaş, 2013) uyum gösterebilmesi beklenir. Dolayısıyla yaş dağılımında 18-25 yaş grubunun katılımcıların yarıdan fazlasını oluşturması yiyecek içecek işletmelerinde tahmin edilebilir bir sonuçtur. Medeni durumları kapsamında, katılımcıların \%80,1'i bekar iken \%19,9'u ise evlidir. Yiyecek içecek işletmelerindeki yoğun iş temposu, evli çalışanların aileleriyle birlikte zaman geçirmesine yeterli imkan vermemektedir (Taşlıyan, 2007: 190). Bundan dolayı evli çalışanlar, yiyecek içecek işletmelerinde çalışmayı daha az tercih etmektedir. Eğitim durumları değerlendirildiğinde üniversite eğitimi alanların katılımcıların yaklaşık yarısını oluşturduğu görülmüsştür. Hizmet 
kalitesinin artırılması açısından eğitim önemli yer tutar (Duman vd., 2006) ve araştırma kapsamındaki yiyecek içecek işletmelerinin işe alımlarda tercihlerini nitelikli çalışan yönünde yaptıkları anlaşılmaktadır. Yiyecek içecek işletmelerinde çalışanlara verilen hizmetin bedeline ek olarak verilen bahşiş ve asgari ücretin 1603 TL olması sebebiyetiyle katılımcıların büyük çoğunluğunun aylık gelirinin 1501 ve 2500 TL civarında olması araştırmada beklenen bir sonuçtur. Sürekli çalışan sayısının fazla olması $(\% 74,8)$ da yasalardaki mecburi sigorta uygulamalarıyla açıklanabilir. Katılımcıların yarısının 18-25 yaşları arasında olması ve eğitimlerine devam ediyor olmaları part-time çalışma şeklinin tercih edilmesi bir öğrenci şehri olan Eskişehir açısından olağan bir sonuçtur. Katılımcıların \%5,3'ü temizlik görevlisi, \%49,6's1 servis görevlisi, \%10,3'ü yönetici, \%8,1'i bar personeli, \%11,1'i mutfak personeli, $\% 7,8^{\prime}$ i mutfak şefi, \%4,8'i kasiyer, \%1,5'i karşılama görevlisi ve \%1,5'i stok görevlisi meslek gruplarında yer almaktadır. Bir yiyecek içecek işletmesinde servisin zamanında ve kaliteli yapılabilmesi için personelin yeterli sayıda olması gerekmektedir. İş yoğunluğunun fazla olduğu yiyecek içecek işletmelerinde servis personelinin daha fazla sayıda olması olağan bir durumdur. Dolayısıyla katılımcıların yarısına yakınının servis görevlisi olması tahmin edilebilir bir sonuçtur. Araştırma sonucunda işletmede çalışma süresinin çoğunlukta 1 yıldan az olması turizmde iş gücü devir hızının yüksekliğiyle paraleldir (Ünlüönen ve Şahin, 2011).

Tablo 2. Değişime Açıklık Ölçeğinin Açıklayıcı Faktör Analizi Sonuçları

\begin{tabular}{|c|c|c|c|c|c|}
\hline \multirow[t]{2}{*}{ Faktörler ve İfadeler } & \multicolumn{3}{|c|}{ Faktör Yükleri } & \multirow[t]{2}{*}{ Ort. } & \multirow[t]{2}{*}{ S.S } \\
\hline & 1 & 2 & 3 & & \\
\hline \multicolumn{6}{|l|}{ Davranışsal Boyut } \\
\hline Değişim kurumun yararına olur. & ,584 & & & 3,98 & 1,02 \\
\hline Değişiklikleri denemeye eğilimliyim. & ,761 & & & 4,05 & ,986 \\
\hline $\begin{array}{l}\text { Değişimler iş yerinde daha yüksek performans göstermeme } \\
\text { yardımcı olur. }\end{array}$ & 674 & & & 3,83 & 1,02 \\
\hline Değişimlerin beni teşvik edici etkisi vardır. & 692 & & & 3,84 & 1,03 \\
\hline $\begin{array}{l}\text { Değişimler kurumdaki istenmeyen durumların iyileştirilmesine } \\
\text { yardımcı olur. }\end{array}$ & 803 & & & 3,92 & 1,02 \\
\hline Değişimlerden kazançlı çıkarım. & & & & & \\
\hline Cronbach's Alpha (a) & ,719 & & 877 & 3,62 & 1,03 \\
\hline \multicolumn{6}{|l|}{$\begin{array}{r}\text { Duygusal Boyut } \\
\end{array}$} \\
\hline $\begin{array}{l}\text { Değişimler eğer benim kurumumda oluyorsa rahatsız olabilirim. } \\
\text { (T) }\end{array}$ & & 838 & & 3,85 & 1,22 \\
\hline Değişikliklerin birçoğu rahatsız edicidir. (T) & & ,686 & & 3,98 & ,992 \\
\hline Değişime direnç gösteririm. $(\mathrm{T})$ & & 623 & & 4,06 & 1,02 \\
\hline Cronbach's Alpha (a) & & & ,698 & & \\
\hline \multicolumn{6}{|l|}{ Bilişsel Boyut } \\
\hline Kurumumda değişim olmasını dört gözle beklerim. & & & 847 & 3,23 & 1,03 \\
\hline Kurumumdaki birçok çalışan değişimlerden olumlu etkilenir. & & & ,618 & 3,55 & 1,10 \\
\hline Diğer çalışanlar benim değişimi destekleyeceğimi düşünür. & & &, 531 & 3,72 & ,975 \\
\hline Cronbach's Alpha (a) & & & ,663 & & \\
\hline Genel Cronbach's Alpha (a) & & & 897 & & \\
\hline Açıklanan Toplam Varyans (\%) & & & 62,548 & & \\
\hline KMO Örneklem Ölçüm Değeri & & & ,938 & & \\
\hline Bartlett Testi & & 5,$933 ;$ & s.d.: 66; & $\mathrm{p} \leq, 000$ & \\
\hline
\end{tabular}


Tablo 3. Büyük Beşli Kişilik Envanterinin Açıklayıcı Faktör Analizi Sonuçları

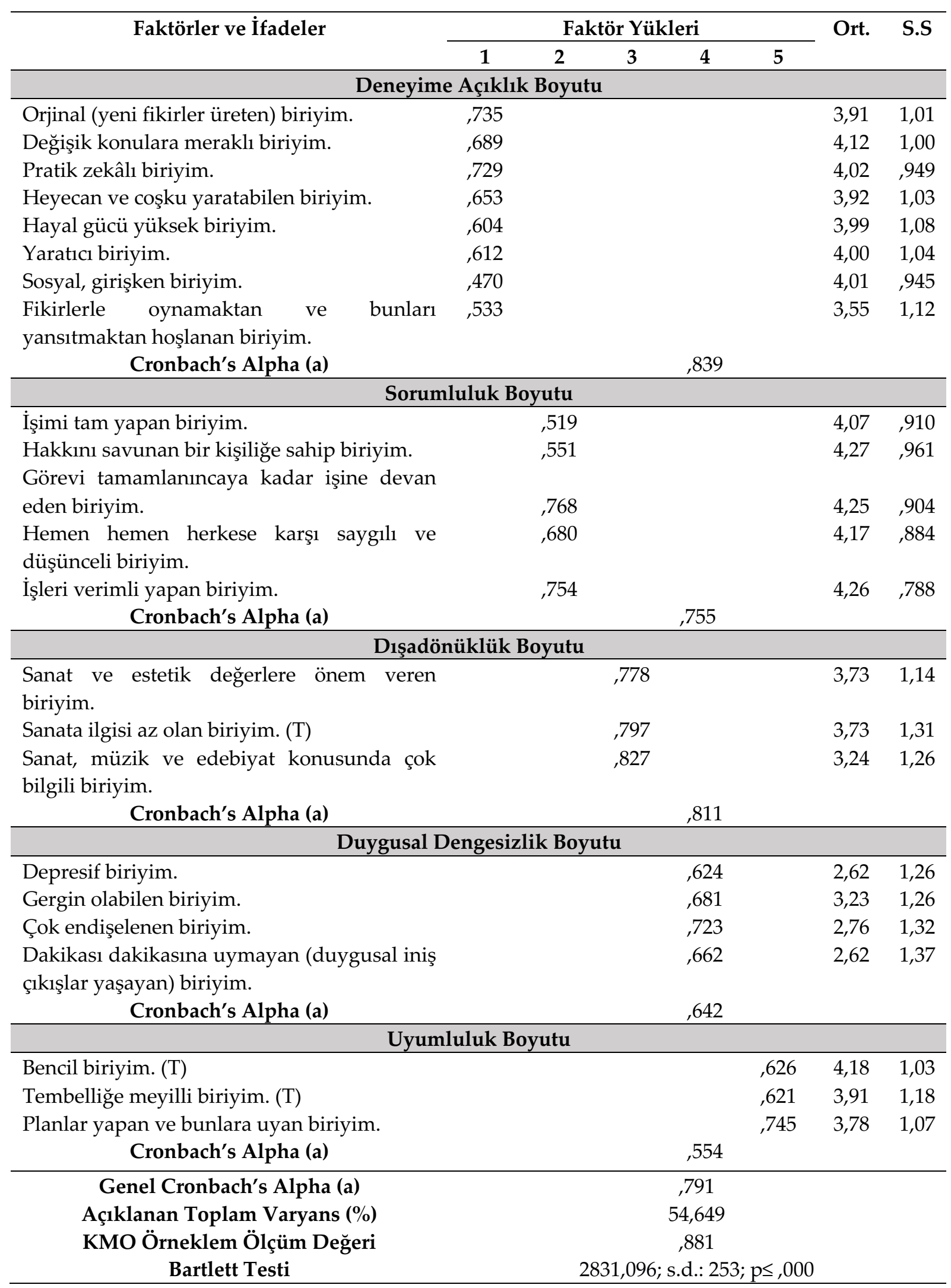

Analizin ikinci aşamasında faktör analizi yapılmadan önce tüm değişkenler arasındaki ilişkinin yeterliliğini açıklayan ve anlamlı faktörler çıkabileceğini gösteren Bartlett Küresellik Testi değerlerine 
bakılmıştır (Hair vd., 2010). Hem Değişime Açıklık Ölçeği'nin hem de Büyük Beşli Kişilik Envanterinin ( $p=0,000<0,05$ ) anlamlılık derecesinde olduğu, birinci ölçeğin Bartlett Küresellik Testi değerinin 1996,933 ikinci ölçek için ise 2831,096 olduğu sonucuna ulaşılmıştır. İkinci aşamada örneklem hacminin yeterliliğini ölçmek ve veri setinin faktör analizine uygun olup olmadığını tespit etmek için KaiserMeyer-Olkin (KMO) değerine bakılmıştır. Değişime Açıklık Ölçeği'nin Kaiser-Meyer-Olkin değeri $(\mathrm{KMO}=0,938)$ ve Büyük Beşli Kişilik Envanterinin değeri ise $(\mathrm{KMO}=0,881)$ alt sınır olan 0,5 üzerinde olması örneklem hacminin yeterli seviyede olduğunu göstermiştir (Kalaycı, 2008). Elde edilen veriler sonucunda araştırmada yer alan ölçeklerin faktör analizi yapmaya uygun olduğu görülmüştür. Değişime Açıklık Ölçeği'nin faktör analizi sonuçları aşağıdaki Tablo 2' de verilmektedir.

Açıklayıcı faktör analizinde ilk olarak veri derleme aracının faktör yapısını görebilmek ve daha iyi yorum yapabilmek adına genellikle kullanılan "Varimax" tekniğinden yararlanılmıştır (Kalaycı, 2008). Analiz sonucunda bazı ifadelerin birden fazla faktörde yüksek değere sahip olması ve geçerli ölçüm değerlerine sahip olmamaları nedeniyle ölçekten çıkartılmıştır (Büyüköztürk, 2002). Bu aşamadan sonra kalan 12 maddeye faktör analizi uygulanmış ve faktör yüklerinin 0,531 ile 0,847 arasında olduğu tespit edilmiştir. Esas alınan Kaiser ölçütüne göre öz değeri 1'den büyük olan ifadeler üç boyut altında toplanmıştır. Bu üç boyutun açıkladıkları toplam varyans \% 62,54'dür. Ayrıca araştırmada, verilerin güvenilirliklerini test etmek amacıyla yaygın olarak kullanılan Cronbach Alfa katsayısına bakılmışır ve yüksek güvenilir düzeyinde $(0,89)$ olarak tespit edilmiştir. Geriye kalan ifadeler "Davranışsal, Duygusal ve Bilişsel" olmak üzere üç boyut altında toplanmıştır. Ölçeğin boyutlarının Cronbach's Alfa değerleri 0,66-0,87 düzeyinde oldukça ve yüksek güvenilir düzeyleri arasında olduğu görülmektedir (Kalayc1, 2008). Bir diğer yararlanılan ölçek olan Büyük Beşli Kişilik Envanterinin faktör analizi sonuçları aşağıdaki Tablo 3'te verilmektedir.

Analiz sonucunda bazı ifadelerin birden fazla faktörde yüksek değere sahip olması ve geçerli ölçüm değerlerine sahip olmamaları nedeniyle ölçekten çıkartılmıştır (Büyüköztürk, 2002). Bu aşamadan sonra kalan 23 maddeye faktör analizi uygulanmış ve faktör yüklerinin 0,470 ile 0,827 arasında olduğu tespit edilmiştir. Esas alınan Kaiser ölçütüne göre öz değeri 1'den büyük olan ifadeler beş boyut altında toplanmıştır. Bu beş boyutun açıkladıkları toplam varyans \% 54,64'dür. Ayrıca Cronbach Alfa katsayısı oldukça güvenilir düzeyde, 0,79 olarak tespit edilmiştir. Geriye kalan ifadeler "Deneyime Açılık, Sorumluluk, Dışadönüklük, Duygusal Dengesizlik, Uyumluluk" olmak üzere beş boyut altında toplanmıştır. Ölçeğin boyutlarının Cronbach's Alfa değerleri 0,55-0,83 düzeyinde düşük ve yüksek güvenilir düzeyleri arasında olduğu görülmektedir (Kalayc1, 2008).

Bir sonraki aşamada çalışmada yer alan temel değişkenlerin birbirleriyle olan ilişkileri ve olası ilişkilerinin kuvvet ve yön derecelerinin tespiti için korelasyon analizi uygulanmıştır. Bulgular incelendiğinde değişime açıklık ile kişilik envanteri, deneyime açıklık, sorumluluk, dışadönüklük ve uyumluluk boyutu arasında pozitif yönlü ilişkiler saptanmıştır. Belirtilen ilişkilerin 0,00 anlamlılık düzeyinde istatistiksel olarak anlamlı olduğu görülmektedir. Değişime açıklık ile duygusal dengesizlik boyutu arasında negatif yönlü ilişki tespit edilmiştir ve 0,03 anlamlılık düzeyinde istatistiksel olarak anlamlı olduğu görülmektedir. Korelasyon katsayıları incelendiğinde, değişime açıklık boyutunun puanı ile kişilik envanteri arasındaki ilişkinin 0,382, deneyime açılık boyutu ile 0,392, sorumluluk boyutu ile 0,327 , dişadönüklük boyutu ile 0,297 , duygusal dengesizlik boyutu ile $-0,148$ ve uyumluluk boyutu ile 0,176 düzeyinde olduğu anlaşılmıştır.

Analizin sonraki aşamasında değişime açıklık bağımlı değişken, kişilik envanteri bağımsız değişken olarak ele alınarak kişilik envanterinin değişime açıklığa olan etkisini araştırmak için regresyon analizi yapılmıştır. Regresyon analizi, bağımlı bir değişken ile bağımlı değişken üzerinde etkisi olduğu varsayılan bağımsız değişken(ler) arasındaki ilişkinin matematiksel bir model ile açılanmasıdır (Ural ve Kılıç, 2006). Bağımsız değişkenin tek olduğu durumlarda kullanılan regresyon analizine "tek değişkenli/basit doğrusal regresyon analizi", birden fazla bağımsız değişkenin olduğu durumlarda kullanılan regresyon analizine ise "çok değişkenli/çoklu regresyon analizi" denir (Altunışık vd., 2001). Çalışmada bir bağımlı bir bağımsız değişkenin bulunması sebebiyle basit doğrusal regresyon analizinin 
yapılmasına karar verilmiştir. Çalışmada gerçekleştirilen basit doğrusal regresyon analizinin sonuçları aşağıdaki Tablo 4 'te gösterilmektedir.

Tablo 4. Kişilik Özelliklerinin Değişime Açıklık Üzerine Etkisini Tespit Etmek Amaçlı Gerçekleştirilen Basit Doğrusal Regresyon Analizi

\begin{tabular}{|c|c|c|c|c|c|c|c|c|}
\hline Değişkenler & $\mathbf{R}$ & $\mathbf{R}^{2}$ & S.S & $\mathbf{F}$ & B & Beta & $\mathrm{T}$ & $\mathbf{P}$ \\
\hline \multicolumn{9}{|l|}{ 1. Aşama } \\
\hline H1 & ,382 & 146 & & 67,638 & & & & \\
\hline Sabit Değer & & & ,272 & & 1,590 & & 5,852 & ,000 \\
\hline Kişilik Envanteri & & & ,072 & &, 590 & ,382 & 8,224 & ,000 \\
\hline \multicolumn{9}{|c|}{ Bağımlı Değişken: Değişime Açıklık } \\
\hline \multicolumn{9}{|c|}{ 2. Aşama } \\
\hline H1 a & 392 & 154 & & 71,728 & & & & \\
\hline Sabit Değer & & & ,188 & & 2,239 & & 11,898 & ,000 \\
\hline Deneyime Açılık & & & 047 & & 398 & 392 & 8,469 & ,000 \\
\hline \multicolumn{9}{|c|}{ Bağımlı Değişken: Değişime Açıklık } \\
\hline \multicolumn{9}{|l|}{ 3. Aşama } \\
\hline H1 b & ,327 & 107 & & 47,142 & & & & \\
\hline Sabit Değer & & & ,228 & & 2,259 & & 9,894 & ,000 \\
\hline Sorumluluk & & & ,054 & & ,368 & ,327 & 6,866 &, 000 \\
\hline \multicolumn{9}{|c|}{ Bağımlı Değişken: Değişime Açıklık } \\
\hline \multicolumn{9}{|c|}{ 4. Aşama } \\
\hline H1 c & ,297 & ,088 & & 38,233 & & & & \\
\hline Sabit Değer & & & 120 & & 3,094 & & 25,679 & ,000 \\
\hline Dişadönüklük & & & ,032 & & ,200 & 297 & 6,183 & ,000 \\
\hline \multicolumn{9}{|c|}{ Bağımlı Değişken: Değişime Açıklık } \\
\hline \multicolumn{9}{|c|}{ 5. Aşama } \\
\hline H1 d & 148 & ,022 & & 8,866 & & & & \\
\hline Sabit Değer & & & ,116 & & 4,136 & & 35,801 & ,000 \\
\hline Duygusal Dengesizlik & & & 039 & &,- 116 &,- 148 & $-2,978$ & ,003 \\
\hline \multicolumn{9}{|c|}{ Bağımlı Değişken: Değişime Açıklık } \\
\hline \multicolumn{9}{|c|}{ 6. Aşama } \\
\hline H1 e & 176 & ,031 & & 12,588 & & & & \\
\hline Sabit Değer & & & 179 & & 3,186 & & 17,800 & ,000 \\
\hline Uyumluluk & & & 044 & & 157 & 176 & 3,548 & ,000 \\
\hline \multicolumn{9}{|c|}{ Bağımlı Değişken: Değişime Açıklık } \\
\hline \multicolumn{9}{|c|}{ 7. Aşama } \\
\hline H1 f & ,415 & 172 & & 82,231 & & & & \\
\hline Sabit Değer & & & 301 & & 1,166 & & 3,868 & ,000 \\
\hline Kişilik Envanteri & & & 080 & & ,722 & ,415 & 9,068 &, 000 \\
\hline \multicolumn{9}{|c|}{ Bağımlı Değişken: Davranışsal } \\
\hline \multicolumn{9}{|c|}{ 8. Aşama } \\
\hline H1 g & ,314 & ,098 & & 43,077 & & & & \\
\hline Sabit Değer & & & 314 & & 1,464 & & 4,667 & ,000 \\
\hline Kişilik Envanteri & & & 083 & &, 544 & 314 & 6,563 & ,000 \\
\hline \multicolumn{9}{|c|}{ Bağımlı Değişken: Bilişsel } \\
\hline \multicolumn{9}{|c|}{ 9. Aşama } \\
\hline H1 h & 202 & 041 & & 16,728 & & & & \\
\hline Sabit Değer & & & ,346 & & 2,565 & & 7,420 & ,000 \\
\hline Kişilik Envanteri & & & ,091 & &, 373 & 202 & 4,090 & ,000 \\
\hline Bağımlı Değişken: Duy & & & & & & & & \\
\hline
\end{tabular}


H1: Basit doğrusal regresyon analizi doğrultusunda kişilik envanterinin (bağımsız değişken), değişime açıklı̆̆ (bağımlı değişken) pozitif yönlü ve anlamlı ( $(=0,590 ; p=0,00<0,05)$ etkilediği görülmektedir. Değişime açıklık ile kişilik envanteri arasındaki etkileşime ait basit doğrusal regresyon modeli; "Değişime Açıklık=1,590+0,590*Kişilik Envanteri” şeklinde oluşmaktadır. Kişilik envanterinin değişime açıklığa etkisi 0,590 düzeyinde olduğu görülmektedir. Aynı zamanda değişime açıklıkta meydana gelen değişimin \%14,6'sı kişilik envanteri ile açıklanabilmektedir. Bu kapsamda kişilik envanteri bir birim arttığında değişime açıklık eğiliminin 0,590 (B) kadar artacağını söylemek mümkündür. Dolayısıyla H1: "Araştırmaya katılan çalışanların kişilik özellikleri değişime açıklı̆̆ı etkiler" hipotezi kabul edilmiştir.

H1 a: Analiz sonucunda kişilik envanterinin boyutu olan deneyime açıklığın (bağımsız değişken), değişime açıklı̆̆ı (bağımlı değişken) pozitif yönlü ve anlamlı $(\Omega=0,398 ; p=0,00<0,05)$ etkilediği görülmektedir. Değişime açıklık ile deneyime açılık arasındaki etkileşime ait basit doğrusal regresyon modeli; "Değişime Açıklık=2,239+0,398*Deneyime Açılık" şeklinde oluşmaktadır. Deneyime açıklık boyutunun değişime açıklığa olan etkisi 0,398 düzeyinde olduğu görülmektedir. Aynı zamanda değişime açıklıkta meydana gelen değişimin \%15,4'ünü deneyime açılık boyutu ile açıklanabilmektedir. Bu kapsamda deneyime açıklık bir birim arttığında değişime açıklık eğiliminin 0,398 (B) kadar artacağını söylemek mümkündür. Analizler sonucunda H1a: "Araştırmaya katılan çalışanların deneyime açıklık özelliği değişime açıklığı etkiler" hipotezi kabul edilmiştir.

H1 b: Yapılan analiz sonucunda kişilik envanterinin sorumluluk boyutu (bağımsız değişken), değişime açıklığı (bağımlı değişken) pozitif yönlü ve anlamlı $(B=0,368 ; p=0,00<0,05)$ bir şekilde etkilediği görülmektedir. Değişime açıklık ile sorumluluk boyutu arasındaki etkileşime ait basit doğrusal regresyon modeli; "Değişime Açıllık=2,259+0,368*Sorumluluk" şeklinde gerçekleşmektedir. Sorumluluk boyutunun değişime açılığa olan etkisi 0,368 düzeyinde olduğu görülmektedir. Aynı zamanda değişime açıklıkta meydana gelen değişimin \%10,7'si sorumluluk boyutu ile açıklanabilmektedir. Dolayısıyla sorumluluk bir birim arttığında değişime açıklık eğiliminin 0,368 (B) kadar artacağı söylenebilir. Analizler sonucunda H1b: “Araştırmaya katılan çalışanların sorumluluk bilinci değişime açılığı etkiler" hipotezi kabul edilmiştir.

H1 c: Gerçekleştirilen basit doğrusal regresyon analizi kapsamında kişilik envanterinin boyutlarından biri olan dışadönüklük (bağımsız değişken), değişime açıklığı (bağımlı değişken) pozitif yönlü ve anlamlı $(\Re=0,200 ; p=0,00<0,05)$ bir şekilde etkilemektedir. Değişime açıklık ile dışadönüklük arasındaki etkileşime ilişkin basit doğrusal regresyon modeli; "Değişime Açıklık=3,094+0,200*Dışadönüklük" olarak gerçekleşmektedir. Dışadönüklüğün değişime açıklığa etkisi 0,200 düzeyindedir. Ayrıca değişime açıklıkta meydana gelen değişimin \%8,8'i dışadönüklük ile açıklanabilmektedir. Sonuç olarak dışadönüklük bir birim arttığında değişime açıklık eğiliminin 0,200 (ß) kadar artacağı ifade edilebilir. Analizler sonucunda H1c: "Araştırmaya katılan çalışanların dışadönüklüğü değişime açıklığı etkiler" hipotezi kabul edilmiştir.

H1 d: Analiz sonucunda kişilik envanterinin boyutlarından duygusal dengesizlik (bağımsız değişken), değişime açıklı̆̆ (bağımlı değişken) negatif yönlü ve anlamlı $(\Omega=-0,116 ; p=0,03<0,05)$ bir şekilde etkilemektedir. Değişime açıklık ile duygusal dengesizlik arasındaki etkileşime ait basit doğrusal regresyon modeli; "Değişime Açıklık=4,136+(-0,116)*Duygusal Dengesizlik" şeklinde oluşmaktadır. Duygusal dengesizliğin değişime olan açıklığa etkisi -0,116 düzeyinde olduğu görülmektedir. Ayrıca değişime açıklıkta meydana gelen değişimin \%2,2'si duygusal dengesizlik boyutu ile açıklanabilmektedir. Bu kapsamda duygusal dengesizlik bir birim arttığında değişime açıklık eğiliminin -0,116 (ß) kadar artacağını söylemek mümkündür. Analizler doğrultusunda H1d: "Araştırmaya katılan çalışanların duygusal dengeleri değişime açıklı̆̆ı etkiler" hipotezi kabul edilmiştir.

H1 e: Gerçekleştirilen basit doğrusal regresyon analizi ile kişilik envanterinin boyutlarından biri olan uyumluluk (bağımsız değişken), değişime açıklı̆̆ı (bağımlı değişken) pozitif yönlü ve anlamlı $(§=0,157$; $\mathrm{p}=0,00<0,05)$ bir şekilde etkilediği görülmektedir. Değişime açıklık ile uyumluluk arasındaki etkileşime dair basit doğrusal regresyon modeli; "Değişime Açılık=3,186+0,157*Uyumluluk" şeklinde 
gerçekleşmektedir. Uyumluluğun değişime olan açılığa etkisi 0,157 düzeyindedir. Aynı zamanda değişime açıklıkta meydana gelen değişimin \%3,1'i uyumluluk ile açılanabilmektedir. Bu doğrultuda, uyumluluk bir birim arttığında değişime açıklık eğiliminin 0,157 (ß) kadar artacağı söylenebilir. Analizler sonucunda H1e: "Araştırmaya katılan çalışanların uyumluluğu değişime açıklı̆̆ etkiler" hipotezi kabul edilmiştir.

H1 f: Yapılan basit doğrusal regresyon analizi ile kişilik envanteri (bağımsız değişken), değişime açıklık boyutlarından biri olan davranışsal boyutu (bağımlı değişken) pozitif yönlü ve anlamlı ( $(=0,722$; $\mathrm{p}=0,00<0,05)$ şekilde etkilediği görülmektedir. Davranışsal boyut ile kişilik envanteri arasındaki etkileşime ait basit doğrusal regresyon modeli; "Davranışsal Boyut=1,166+0,722*Kişilik Envanteri" şeklinde oluşmaktadır. Kişilik envanterinin davranışsal boyuta etkisi 0,722 düzeyinde olduğu görülmektedir. Ayrıca davranışsal boyutta oluşan değişimin \%17,2'si kişilik envanteriyle açıklanabilmektedir. Dolayısıyla kişilik envanteri bir birim arttığında değişimin davranışsal eğilimi 0,722 (ß) kadar artacağı söylenebilir. Analizler doğrultusunda H1f: “Araştırmaya katılan çalışanların kişilik özellikleri değişimin davranışsal boyutunu etkiler" hipotezi kabul edilmiştir.

H1 g: Analiz sonucunda kişilik envanterinin (bağımsız değişken), değişime açıklık boyutlarından bilişsel boyutu (bağımlı değişken) pozitif yönlü ve anlamlı ( $(=0,544 ; \mathrm{p}=0,00<0,05)$ bir şekilde etkilediğini söylemek mümkündür. Bilişsel boyut ile kişilik envanterinin etkileşimine dair basit doğrusal regresyon modeli; “Bilişsel Boyut=1,464+0,544*Kişilik Envanteri” şeklinde gerçekleşmektedir. Kişilik envanterinin bilişsel boyuta etkisi 0,544 düzeyinde yer almaktadır. Ayrıca bilişsel boyutta oluşan değişimin \%9,8'i kişilik envanteriyle açıklanabilmektedir. Bu kapsamda kişilik envanteri bir birim arttığında değişimin bilişsel eğilimi 0,544 (ß) kadar artacağını söylemek mümkündür. Analizler sonucunda H1g: "Araştırmaya katılan çalışanların kişilik özellikleri değişimin bilişsel boyutunu etkiler" hipotezi kabul edilmiştir.

H1 h: Gerçekleştirilen basit doğrusal regresyon analiziyle kişilik envanteri (bağımsız değişken), değişime açıklık boyutlarından biri olan duygusal boyutu (bağımlı değişken) pozitif yönlü ve anlamlı $(ß=0,373 ; p=0,00<0,05)$ bir şekilde etkilemektedir. Duygusal boyut ile kişilik envanteri arasındaki etkileşime ait basit doğrusal regresyon modeli; "Duygusal Boyut=2,565+0,373*Kişilik Envanteri" şeklinde gerçekleşmektedir. Kişilik envanterinin duygusal boyuta olan etkisi 0,373 düzeyinde yer aldığ1 görülmektedir. Aynı zamanda duygusal boyutta meydana gelen değişimin \%4,1'i kişilik envanteriyle açıklanabilmektedir. Dolayısıyla kişilik envanteri bir birim arttığında değişimin duygusal eğilimi 0,373 (ß) kadar artacağı söylenebilir. Analizler sonucunda H1h: "Araştırmaya katılan çalışanların kişilik özellikleri değişimin duygusal boyutunu etkiler" hipotezi kabul edilmiştir. Sonuç olarak kişilik envanteri değişime açıklığı 0,590 düzeyinde etkilemektedir. Ayrıca değişime açıklığı en çok etkileyen kişilik envanterinin faktörleri sırasıyla deneyime açıklık $(0,398)$, sorumluluk $(0,368)$, dişadönüklük $(0,200)$, uyumluluk $(0,157)$ ve duygusal dengesizlik $(-0,116)$ olduğu görülmektedir. Kişilik envanterinin değişime açıklık boyutları üzerindeki etkisi ise davranışsal $(0,722)$, bilişsel $(0,544)$ ve duygusal $(0,373)$ şeklinde gerçekleşmiştir.

Araştırmanın son aşamasında demografik özellikler ve istihdam özellikleri değişkenlerinin değişime açıklığa olan ilişkisi açısından incelenmesine olanak tanıması nedeniyle Bağımsız Örneklem T-testi ve One-way Anova testinin de uygulanmasına karar verilmiştir. Analiz sonucunda çalışanların kurumdaki pozisyonlarının dışında yer alan diğer demografik özellikler ile değişime açıklık arasında farklılık olmadığı sonucuna ulaşılmıştır (Kayri, 2009: 58). Restoranda çalışanların pozisyonları ile değişime açıklık arasında $(\mathrm{F}(8-388)=2,616, \mathrm{p}=0,008<0,05)$ ise anlamlı bir farklılık olduğu görülmüştür. $\mathrm{Bu}$ farklılığın kaynağını bulmak amacıyla yapılan çoklu karşılaştırma testlerinden Tukey HSD testi sonuçlarına göre yönetici pozisyonunda çalışanlarla $(x=4,1341)$ mutfak personeli pozisyonunda çalışanlar $(x=3,4943)$ arasında değişime açıklık bakımından anlamlı $(\mathrm{p}=0,001<0,05)$ bir fark olduğu belirlenmiştir. Elde edilen bulgulara ilişkin değerlendirmelere, literatür çerçevesinde yorumlara ve analizlere ilişkin çıkarsamalara sonuç ve öneriler kısmında yer verilmiştir. 


\section{SONUÇ VE ÖNERILER}

Restoran gibi hizmet yoğun işletmelerde çalışanların önemi büyüktür. Çünkü çalışanların davranışları hizmetin kalitesini etkilediği gibi işletme tarafından verilen kararların uygulanmasında da önemli yer tutmaktadır. Cox vd., (2011) yaptıkları çalışmada restoran işletmelerinin değişime ayak uydurması gerektiğini belirtmektedirler. Dolayısıyla işletmeler değişim sürecine girdiklerinde başarılı olabilmeleri için çalışanların davranışlarında etkili olan kişilik özelliklerine önem göstermeleri gerekmektedir (Drake ve Smith, 1978). Çünkü değişimi uygulayacak olanlar çalışanlardır. Dolayısıyla değişim sürecine giren işletmelerde değişime uygun kişilerin yer alması, değişimin geleceğini olumlu etkileyecektir (Hammer ve Champy, 1994).

Duygusal dengesizlik özelliğine sahip çalışanlar; tutarsız ve dengesiz kişilerdir. Hammer ve Champy (1994), Bergey vd., (1999) ve Thomas (1996) değişimin başarısında vazgeçmeme ve tutarlı olma özelliğinin etken olduğunu belirtmektedirler. Dolayısıyla çalısmanın sonucu olarak duygusal dengesizliğin değişime açıklık ile arasında negatif ve düşük seviyede ilişkinin olması tahmin edilebilir bir sonuçtur (Raja, vd., 2004). Ayrıca Arslan (2017), Özkan (2017) ve Serçeoğlu (2013) otel çalışanları üzerine yaptıkları çalışmalarda duygusal dengesizlik özelliğinin araştırmaları üzerinde negatif etkisi olduğu diğer kişilik boyutlarının ise pozitif etkisinin olduğu sonucuna ulaştıkları görülmektedir. Sun ve Jin (2009) çalışmasında yer alan uyumluluk özelliğinin sonuçlarıyla çalışmamızın sonuçlarının örtüşmesinin nedeni olarak uyumluluk özelliği taşıyan çalışanlar geleneksel yöntemlerle çalıştığından düşük düzeyde ilişki tespiti tahmin edilen bir sonuçtur. Dışadönük özelliği sahip çalışanların yaratıcı özelliğe (Sun ve Jin, 2009) sahip olması nedeniyle değişime açık olması beklenen diğer bir sonuçtur. Özen (2011) belirttiği sorumluluk özelliğinde; bir görevin tamamlanması için gereken çabayı göstermesi durumunun, değişimin başarısında etken rol üstlenen vazgeçmeme özelliği (Hammer ve Champy, 1994; Bergey, vd., 1999 ve Thomas, 1996) ile arasındaki ilişkinin sonuçlara yansıdığı görülebilmektedir. Judge ve Bono (2000) ve Feist ve Feist (2008) çalışmalarında belirttikleri deneyime açık kişilerin değişime açık olması durumunun çalışmamanın sonuçlarında da yer aldığı görülmektedir. Çünkü deneyime açıklık özelliği taşıyan çalışanların, hayal gücü yüksek, yaratıcı, meraklı, açık fikirli, değişikliği seven ve değişime açık kişilerdir (Trapnell ve Wiggins, 1990: 785). Burada da deneyime açılık ile değişime açıklık arasındaki bağın en fazla olması deneyime açıklı̆̆ın barındırdığı özellikler nedeniyle olduğu söylenebilir. Duygusal tutum; çalışanların değişimden mutlu olmasını ifade eder ve duygusal tutum içerisindeki çalışan diğer çalışanlara değişimi desteklemeleri için önerilerde bulunur (Dunham, vd., 1989). Ancak değişimden mutlu olmayan çalışan değişime karşı direncin temelini oluşturur. Ayrıca değişim içerisinde çalışanların değişime katılmaları ve bu katılımlarını davranışsal eyleme dönüştürmesi gerekmektedir. Dolayısıyla duygusal tutumun kişilik özellikleriyle değişime açıklık arasındaki ilişkinin düşük olması literatürle örtüşmektedir Bilişsel tutum; çalışanların, değişimin olumlu getirisine inanma durumudur. Değişimin olumlu sonuçlarına inanılması durumunun değişime açık çalışanlar üzerinde daha fazla hissedildiği söylenebilir. Dolayısıyla değişimi benimseyen çalışanların istihdam edilmesi başarıyı artıraccaktır. Cochran, Bromley ve Swanda (2002), Hamlin vd., (2001) ve Jones vd., (2005) yaptıkları çalışmada değişime karşı pozitif tutum ve duyguların değişime açıklığı olumlu etkilediği sonucunun bu araştırmayla da desteklenmektedir. Davranışsal tutum ise; çalışanın, değişimin içerisinde yer alması ve katkı sağlaması durumudur (Dunham, vd., 1989). Dolayısıyla davranışsal tutum arasında orta düzeyde bir ilişkinin varlığı görülmüştür. Çünkü değişimden beklenen sonuçları alabilmek için değişime katılım önemlidir. Çalışanların değişime inanmaları kadar davranışlarına da bunu yansıtmaları gerekmektedir. Weiner vd., (2008) ve Andrews ve Stalick (1994) çalışanların davranışsal açıdan değişimi desteklemelerinin değişimin başarısı açısından önemli olduğu sonucunun bu çalışmada da yerini aldığı ve kişilik ile arasındaki bağın en fazla olduğu görülmektedir.

Sonuç olarak değişimin başarılı olabilmesi için çalışanların değişime açık ve değişimi desteklemeleri gerekmektedir. Ayrıca çalışanların psikolojik ve davranışsal olarak benzer seviyelerde olması değişime karşı direncin önlenmesinde önemli bir rol oynamaktadır (Weiner vd., 2008). Buradan hareketle değişim sürecine giren işletmelerin değişime açık kişilik özelliklerine sahip çalışanları işe almaları amaçlarına 
ulaşmada katkı sağlayacaktır. Ayrıca değişime karşı çıkanlar için iyi bir eğitim ve ödüllendirme sistemi sayesinde bu direnç kırılabilir.

Özetle, kişiliğin değişime açıklı̆ı etkilediği sonucuna ulaşılmıştır. Dolayısıyla değişim yapmayı düşünen işletme yöneticilerinin, çalışanları işe alırken değişime açık kişilik özelliğine sahip kişileri tercih etmeleri sürecin başarısı için önemlidir. Bu başarı, işletmeye rekabette kendine yer edinmesini ve bir adım öteye geçmesini sağlayacaktır. Ayrıca farklı bölgelerdeki hizmet işletmelerinde de çalışmalar yürütülebilir. Yöneticilerin kişilik özelliklerinin değişime açıklı̆̆ ile çalışanların değişime açıklığı karşılaştırılabilir. Değişime açıklığın sektörel karşılaştırmaları yapılabilir. Sektörel paydaşların değişime açıklıkları tespit edilerek birbirlerine olan etkileri incelenebilir.

Değişimin başarılı olabilmesi ve işletme hedeflerinin yerine getirilebilmesinde kişilik faktörü önemlidir. Dolayısıyla değişimi düşünen işletmeler işe alımlarında kişilik testleri uygulamalıdır. Değişimin başarılı çıktılar verebilmesi için değişim öncesinde duygusal açıdan dengesiz kişilik özelliklerine sahip çalışanlar tespit edilip operasyondan uzaklaştııılmalıdır. İşletme değişim öncesinde çalışanlarına eğitimler, seminerler ve bilgilendirmeler gerçekleştirmelidir. İşe alımlarda yapılacak değişim kapsamında örnek vaka olayları gerçekleştirilmeli ve işe alınacaklar test edilmelidir. Böylece daha isabetli- bir başka ifadeyle doğru işe doğru kişi - işa alım gerçekleşmiş olur.

\section{KAYNAKÇA}

Akgündüz, Y. ve Akdă̆, G. (2014). İşgörenlerin Kişilik Özelliklerinin Temel Benlik Değerlendirmelerine ve İşten Ayrilma Niyetlerine Etkisi, Yönetim Bilimleri Dergisi, 12(24): 295-318.

Aksu, A. A. (1999). Beş Yıldızlı Otel İşletmelerinde Değişim Mühendisliği ve Uygulanabilirliği Üzerine Bir Araştırma, Gazi Üniversitesi Sosyal Bilimler Enstitüsü, Doktora Tezi, Ankara.

Albayrak, A. (2017). Restoran İşletmelerinin Yenilik Uygulama Durumları: İstanbul'daki Birinci Sınıf Restoranlar Üzerine Bir Çalışma. Journal of Tourism and Gastronomy Studies, 5(3): 53-73.

Altunışık, R., Coşkun, R., Bayraktaroğlu, S. ve Yıldırım, E. (2001). Sosyal Bilimlerde Araştırma Yöntemleri: SPSS Uygulamall, Sakarya: Sakarya Kitabevi.

Andrews, C. D. and Stalick, K. S. (1994). Business Reengineering the Survival Guide, New Jersey: PrenticeHall, Inc.

Armenakis, A. A. and Harris, S. G. (2002). Crafting a Change Message to Create Transformational Readiness, Journal of Organizational Change Management, 15(2): 169-183.

Armenakis, A. A., Harris, S. G. and Mossholder, K. W. (1993). Creating Readiness for Organizational Change, Human Relations, 46(6): 681-703.

Arslan, E. (2017). Otel İşletmelerinde Çalışanların Kişilik Özelliklerinin Örgütsel Bağlllık ve İş Tatmini Üzerine Etkisi, Gazi Üniversitesi Eğitim Bilimleri Enstitüsü, Doktora Tezi, Ankara.

Aydoğmuş, C. (2011). Kişilik Özellikleri ile İş Tatmini İlişkisi Üzerinde Psikolojik Güçlendirme ve Dönüşümcü Liderlik Algısının Etkileri, Hacettepe Üniversitesi Sosyal Bilimler Enstitüsü, Doktora Tezi, Ankara.

Baransel, A. (1993). Çă̆daş Yönetim Düşüncesinin Evrimi, İstanbul: Avcıol Basım Yayın.

Barrick, R. M., Stewart, L. G. and Piotrowski, M. (2002). Personality and Job Performance: Test of the Mediating Effects of Motivation Among Sales Representatives, Journal of Applied Psychology, 87(1): 4351.

Baymur, F. (1996). Genel Psikoloji, (11. Baskı). İstanbul: İnkılap Kitabevi.

Bergey, J., Smith, D., Tiley, S., Weiderman, N. and Woods, S. (1999). Why Reengineering Projects Fail, Pittsburgh: Carnegie Mellon Software Engineering Institute. 
Bingül, B. (2006). Study to Investigate the Relationship Between Crises and Openness to Change in Organizations, Marmara Üniversitesi Sosyal Bilimler Enstitüsü, Yüksek Lisans Tezi, İstanbul.

Burger, J. M. (2006). Kişilik, (Çev: İ. D. Erguvan Sarıŏlu), İstanbul: Kaknüs Yayınları.

Burisch, M. (1984). Approaches to Personality Inventory Construction: A Comparison of Merits, American Psychologist, 39(3): 214-227.

Büyüköztürk, Ş. (2002). Faktör Analizi: Temel Kavramlar ve Ölçek Geliştirmede Kullanımı, Kuram ve Uygulamada Eğitim Yönetimi, 32(32): 470-483.

Champy, J. (1995). Reengineering Management: The Mandate for New Leadership, New York: Harper Collins Publishers, Inc.

Cochran, J.K., Bromley, M.L. and Swando, M.J. (2002). Scheriff's Deputies Receptivity to Organizational Change, Policing: An International Journal of Police Strategies and Management, 25(3): 507- 529.

Coşkun, R., Altunışık, R., Bayraktaroğlu, S. ve Yıldırım, E. (2015). Sosyal Bilimlerde Araştırma Yöntemleri SPSS Uygulamalı, İstanbul: Sakarya Kitabevi.

Cox, R., Davidson, M. and Wilkins, H. (2011). Exploring Innovation Strategies That Affect Business Performance in Restaurants, International Conference on Hospitality \& Leisure Applied Research (I-CHLAR 2011): Balancing Art, Innovation \& Performance, (5): 2015.

Cunningham, C. E., Woodward, C. A., Shannon, H. S., MacIntosh, J., Lendrum, B., Rosenbloom, D. and Brown, J. (2002). Readiness for Organizational Change: A Longitudinal Study of Workplace, Psychological and Behavioural Correlates, Journal of Occupational and Organizational Psychology, 75(4): 377-392.

Çavuş, Ş. (2008). Yönetim Teorisinin Tarihsel Gelişimi ve Turizm İşletmelerinde Çağdaş Yönetim Tekniklerine Geçiş, İçinde: Turizm İşletmelerinde Çağdaş Yönetim Teknikleri (Ed: F. Okumuş ve U. Avcı), Ankara: Detay Yayıncilık.

Develioğlu, K. ve Tekin, Ö. A. (2013). Beş Faktör Kişilik Özellikleri ve Yabancılaşma Arasındaki İlişki: Beş Yıldızlı Otel Çalışanları Üzerine Bir Uygulama, Süleyman Demirel Üniversitesi İktisadi ve İdari Bilimler Fakültesi Dergisi, 18(2): 15-30.

Devos, G., Buelens, M. and Bouckenooghe, D. (2007). Contribution of Content, Context, and Process to Understanding Openness to Organizational Change: Two Experimental Simulation Studies, The Journal of Social Psychology, 147(6): 607-630.

Drake, R. I. ve Smith, P. J. (1978). Sanayide Davranış Bilimleri, (Çev: K. Tosun, İ. Erdoğan, F. Aykar, T. Somay ve C. Baysal), İstanbul: Fatih Yayınevi Matbaası.

Duman, T., Tepeci, M. ve Unur, K. (2006). Mersin'de Yükseköğretim ve Ortaöğretim Düzeyinde Turizm Eğitimi Almakta Olan Öğrencilerin Sektörün Çalışma Koşullarını Algılamaları ve Sektörde Çalışma İsteklerinin Karşılaştırmalı Analizi, Anatolia: Turizm Araştırmaları Dergisi, 17(1): 51-69.

Dunham, R. B., Grube, J. A., Gardner, D. G., Cummings, L. L. and Pierce, J. L. (1989). The Development of An Attitude Toward Change Instrument, Academy of Management Annual Meeting, Washington, DC.

Ertürk, Y. D. (2010). Davranış Bilimleri, (3. Baskı). İstanbul: Kutup Yıldızları Yayınları.

Feist, J. and Feist, J. G. (2008). Theories of Personality, (7. Bask1). New York: McGraw-Hill.

George, J. M. and Jones, G. R. (1996). Understanding and Managing Organizational Behavior, New York: Addison-Wesley Publishing Company.

Gök, Y. N. (2016). Değiş̧im Mühendisliği (bpr) ve Örnek Uygulamalar, Beykent Üniversitesi Sosyal Bilimler Enstitüsü, Yüksek Lisans Tezi, İstanbul. 
Hair, J. F., Black W., Babin, B. and Anderson, R. E. (2010). Multivariate Data Analysis: A Global Perspective, (7. Baskı). New Jersey: Pearson Prentice-Hall.

Hamlin, B., Keep, J. and Ash, K. (2001). Organizational Change and Development: A Reflective Guide for Managers, Trainers and Developers. London: Pearson Education.

Hammer, M. ve Champy, J. (1994). Değişim Mühendislĭği İ̧̧ İdaresinde Devrim İçin Bir Manifesto, (Çev: S. Gül), İstanbul: Gençlik Yayınları.

Hammer, M. ve Santon, A. S. (1995). Değişim Mühendisliği Deorimi, Ne Yapmalı Ne Yapmamalı?, (Çev: S. Gül), İstanbul: Sabah Kitapları.

Heine, S. J. ve Buchtel, E. E. (2009). Personality: The Universal and the Culturally Specific, Annual Review of Psychology, 60: 369-394.

Hellriegel, D. and Slocum, J. W. (2004). Organizational Behavior, (10. Bask1). Quebec: Thomson SouthWestern.

Holt, D. T., Armenakis, A. A., Feild, H. S. and Harris, S. G. (2007). Readiness for Organizational Change: The Systematic Development of A Scale, The Journal of Applied Behavioral Science, 43(2): 232-255.

Hough, L. M. (1992). The Big Five Personality Variables Construct Confusion: Description versus prediction, Human Performance, 5(1-2): 139-155.

John, O. P., Donahue, E. M. and Kentle, R. L. (1991). The Big Five Inventory-Versions 4a and 54. Institute of Personality and Social Research, Berkeley: University of California, Berkeley.

John, P. O., Angleitner A. and Ostendorf, F. (1988). The Lexical Approach to Personality: A Historical Review of Trait Taxonomic Research, European Journal of Personality, 2(3): 171-203.

Jones, R. A., Jimmieson, N. L. and Griffiths, A. (2005). The Impact of Organizational Culture and Reshaping Capabilities on Change Implementation Success: The Mediating Role of Readiness for Change, Journal of Management Studies, 42(2): 361-386.

Judge, A. T. and Bono, E. J. (2000). Five-Factor Model of Personality and Transformational Leadership, Journal of Applied Psychology, 85(5): 751-765.

Kalaycı, Ş. (2008). SPSS Uygulamalı Çok Değişkenli İstatistik Teknikleri, (3. Baskı). Ankara: Asil Yayın Dağıtım.

Kayri, M. (2009). Araştırmalarda Gruplararası Farkın Belirlenmesine Yönelik Çoklu Karşılaştırma (PostHoc) Teknikleri, Firat Üniversitesi Sosyal Bilimler Dergisi, 19(1): 51-64.

Klecker, B.M. and Loadman W.E. (1999). Measuring Principals' Openness to Change on Three Dimensions: Affective, Cognitive and Behavioral, Journal of Instructional Psychology, 26(4): 213-227.

Koçel, T. (2015). İşletme Yöneticiliği, İstanbul: Beta Basım Yayım Dağıtım A.Ş.

Kozak, M. (2015). Bilimsel Araştırma: Tasarım, Yazım ve Yayım Teknikleri, (2. Baskı). Ankara: Detay Yayıncilı.

Kozak, M. A. ve Güçlü, H. (2003). Turizm İşletmelerinde Değişim Yönetimi Üzerine Kavramsal Bir İnceleme, Endüstri İlişkileri ve İnsan Kaynakları Dergisi, 5(1). http://www.isguc.org (Erişim tarihi: 12.11.2017).

Kozak, M. A. (2004). Deģ̆̌işim Yönetimi Otel İşletme Müdürlerinin Değişim Yönetimi ile İlgili Algılamaları Üzerine Bir Araştırma, Ankara: Detay Yayıncılık.

Lester, P. E., Inman, D. and Bishop, L. K. (2014). Handbook of Tests and Measurement In Education and The Social Sciences, (3. Bask1). London: Rowman \& Littlefield.

Manganelli, L. R. and Klein, M. M. (1994). The Reengineering Handbook: A Step by Step Guide to Business Transformation, New York: American Management Association (AMACOM). 
Matthews, G. (1997). Extraversion, Emotion and Performance: A Cognitive-Adaptive Model, İçinde: Advances in Psychology (Ed: G. Matthews), North-Holland: Elsevier Science B. V.

Mc Adams, D.P. (1997). A Conceptual History of Personality Psychology, İçinde: Handbook of Personality Psychology (Ed: R. Hogan, J. Johnson ve S. Briggs), San Diego: Academic Press.

McCrae, R. R. and Costa, P. T. (1985). Comparison of EPI and Psychoticism Scales With Measures of The Five-Factor Model of Personality, Personality and Individual Differences, 6(5): 587-597.

McCrae, R. R. and Costa, P. T. (1987). Validation of the Five-Factor Model of Personality Across Instruments and Observers, Journal of Personality and Social Psychology, 52(1): 81-90.

McCrae, R. R. and Costa, T. P. (2003). Personality In Adulthood: A Five Factor Theory Perspective, (2. Bask1). New York: The Guilford Press.

Moberg, J. P. (2001). Linking Conflict Strategy to The Five-Factor Model: Theoretical and Empirical Foundations, The International Journal of Conflict Management, 12(1): 47-68.

Morris, M. W., Williams, K. Y., Leung, K., Larrick, R., Mendoza, M. T., Bhatnagar, D., Li, J., Kondo, M., Luo, J. L. and $\mathrm{Hu}$, J. C. (1998). Conflict Management Style: Accounting for Cross-National Differences, Journal of International Business Studies, 29(4): 729-747.

Myers, D. ve Dewall, N. C. (2017). Psikoloji, (Çev: A. D. Batıün, F. Y. Tekizoğlu, İ. Yiğit, M. G. Yiğit), (11. Baskı). Ankara: Palme Yayıncilı.

Nunnally J.C. (1978). Psychometric Theory, (2. Baskı). Newyork: Mc Graw Hill.

Örs, F. ve Tetik, S. (2010). Küreselleşen Dünya'da Yeni Yönetim Paradigmaları: Değişim ve İletişim, Çukurova Üniversitesi Sosyal Bilimler Enstitüsü Dergisi, 19(3): 439-456.

Özen, Y. (2011). Kişisel Sorumluluk Bağlamında Kariyer Seçimini Etkileyen Sosyal Psikolojik Faktörler, Eğitim ve İnsani Bilimler Dergisi: Teori ve Uygulama, 2(3): 81-96.

Özkan, Ç. (2017). Algılanan Örgütsel Desteğin, Örgütsel Bă̆lllığa Etkisinde Kişilik Özelliklerinin Rolü: Otel İsletmelerinde Bir Araştırma. Onsekiz Mart Üniversitesi Sosyal Bilimler Enstitüsü, Doktora Tezi, Çanakkale.

Raja, U, Johns, G. and Ntalianis, F. (2004). The Impact of Personality On Psychological Contracts, Academy of Management Journal, 47(3): 350-367.

Salgado, F. J., Viswesvaran, C. and Ones, S. D. (2001). Predictors Used for Personnel Selection: An Overview of Constructs, Methods End Techniques, İçinde: Handbook of Industrial, Work and Organizational Psychology: Volume 1 Personnel Psychology (Ed: N. Anderson, D. S. Ones, H. K. Sinangil ve C. Viswesvaran), California: SAGE Publications Inc.

Saucier, G. and Goldberg, R. L. (1996). Evidence for The Big Five In Analyses of Familiar English Personality Adjectives, European Journal of Personality, 10(1): 61-77.

Schermerhorn, J. R., Hunt, J. G. and Osborn, R. N. (2000). Organizational Behavior, (7. Bask1). New York: John Wiley \& Sons, Inc.

Schmitt, D. P., Allik, J., McCrae, R. R. and Benet-Martinez, V. (2007). The Geographic Distribution of Big Five Personality Traits: Pattern and Profiles of Human Self-description Across 56 nations, Journal of Cross-Cultural Psychology, 38(2): 173-212.

Serçeoğlu, N. (2013). Konaklama İşletmelerinde Çalışan İş Görenlerin Kişilik Özelliklerinin Hizmet Verme Yatkınlığı Üzerindeki Etkisi, Journal of Yaşar University, 8(31): 5253-5273.

Simon, A. K. (1994). Towards A Theoretical Framework for Business Process Reengineering, Studies In The Use of Information Technologies, Department of Informatics, Göteborg University. 
Somer, O., Korkmaz, M. ve Tatar, A. (2002). Beş Faktör Kişilik Envanterinin Geliştirilmesi-I: Ölçek ve Alt Ölçeklerinin Oluşturulması, Türk Psikoloji Dergisi, 17(49): 21-33.

Sun, Y. S. and Jin, N. C. (2009). Do Big Five Personality Factors Affect Individual Creativity? The Moderating Role of Extrinsic Motivation, Social Behavior and Personality, 37(7): 941-956.

Matthews, G. (1997). Extraversion, Emotion and Performance: A Cognitive-Adaptive Model, İçinde: Advances in Psychology (Ed: G. Matthews), North-Holland: Elsevier Science B. V.

Şahin, M. (2008). Durumsallık Yaklaşımı, İçinde: Yönetim ve Organizasyon (Ed: C. Koparal), Eskişehir: Anadolu Üniversitesi Açıköğretim Yayınları.

Şahin, M. (2008). Sistem Yaklaşımı, İçinde: Yönetim ve Organizasyon (Ed: C. Koparal), Eskişehir: Anadolu Üniversitesi Açıöğretim Yayınları.

Şimşek, M. Ş., Akgemci, T. ve Çelik, A. (2003). Davranış Bilimlerine Giriş ve Örgütlerde Davranı̧̧. (3. Baskı). Konya: Adım Matbaacilık \& Ofset.

Şimşek, Ö. (2006). İnsan Dinamiği Kişilik Özelliklerinin İncelenmesine Yönelik Ölçek Geliştirme Çalışması, Sakarya Üniversitesi Sosyal Bilimler Enstitüsü, Yüksek Lisans Tezi, Sakarya.

Şimşek, Ş. M. (2002). Yönetim ve Organizasyon, Konya: Günay Ofset.

Şimşek, A. ve Çetinkaya, N. (2017). Yiyecek-İçecek İşletmeleri Personelinin Kişilik Özellikleri ile İşe Bağlılıkları Arasındaki İlişki, Akademik Bakış Uluslararası Hakemli Sosyal Bilimler Dergisi, (64): 529-543.

Tabachnick, B. G. and Fidell, L. S. (2007). Using Multivariate Statistics, Boston: Allyn and Bacon, Pearson Education.

Tan, M. (2017). Otel İşletmelerinde İşgörenlerin Kişilik Özellikleri ile Sanal Kaytarma Davranışı Arasındaki İlişkinin Analizi, Süleyman Demirel Üniversitesi Sosyal Bilimler Enstitüsü, Yüksek Lisans Tezi, Isparta.

Taşlıyan, M. (2007). Turizm ve Seyahat Sektöründe Çalışanların İş Tatmini ile Müşterilerin Memnuniyeti Arasındaki İlişki: Kahramanmaraş'ta Bir Alan Çalışması, Karamanoğlu Mehmetbey Üniversitesi Sosyal ve Ekonomik Araştırmalar Dergisi, 9(12): 185-195.

Thomas, C. J. C. (1996). Initiating and Preparing for Re-engineering, İçinde: Business Process Reengineering: Myth\&Reality (Ed: C. C. Thomas), London: Kogan Page Limited.

Tolan, B., İsen, G. ve Batmaz, V. (1991). Sosyal Psikoloji, Ankara: Adım Yayıncılık.

Trapnell, D. P. and Wiggins, S. J. (1990). Extension of The Interpersonal Adjective Scales to Include The Big Five Dimensions of Personality, Journal Of Personality And Social Psychology, 59(4): 781-790.

Tuncer, M. ve Yeşiltaş, M. (2013). Çalışma Yaşam Kalitesinin Otel İşletmesi Çalışanları Üzerindeki Etkileri, İ̧sletme Araştırmaları Dergisi, 5(1): 57-78.

Ural, A. ve Kılıç, İ. (2006) Bilimsel Araştırma Süreci ve SPSS ile Veri Analizi, Detay Yayıncılık: Ankara.

Usal, A. ve Aslan, Z. (1995). Davranış Bilimleri Sosyal Psikoloji, İzmir: Fakülteler Kitabevi Barış Yayınları.

Usal, A. ve Kuşluvan Z. (1998). Davranış Bilimleri Sosyal Psikploji, (2. Baskı). İzmir: Barış Yayınları Fakülteler Kitabevi.

Ünlüönen, K. ve Şahin, S. Z. (2011). Turizmde İstihdam, Elektronik Sosyal Bilimler Dergisi, 10 (37): 1-25.

Weiner, B. J., Amick, H. and Lee, S. Y. D. (2008). Conceptualization and Measurement of Organizational Readiness for Change: A Review of the Literature In Health Services Research and Other Fields, Medical Care Research and Review, 65(4): 379-436.

Yazıcıoğlu, Y. ve Erdoğan, S. (2014). SPSS Uygulamalı Bilimsel Araştırma Yöntemleri, (4. Baskı). Ankara: Detay Yayıncılık. 
Yelboğa, A. (2006). Kişilik Özellikleri ve İş Performansı Arasındaki İlişkinin İncelenmesi, İş, Güç Endüstri İlişkileri ve Insan Kaynakları Dergisi, 8(2): 196-211.

Yıldırım, I. B. (2014). Çalışanların Beş Faktör Kişilik Özellikleri ile İş Tatminleri Arasındaki İlişki: Alanya'daki Beş Yıldızlı Oteller Üzerine Bir Uygulama, Akdeniz Üniversitesi Sosyal Bilimler Enstitüsü, Doktora Tezi, Antalya. 